\title{
Posterholt, a Late Pleistocene - Holocene record of the vegetation history in and around the valley of the Vlootbeek, a tributary of the river Meuse (southeastern Netherlands)
}

\section{Corrie Bakels*}

Faculty of Archaeology, Leiden University, Leiden, The Netherlands

* Corresponding author: Email: c.c.bakels@arch.leidenuniv.nl

Manuscript received: 10 May 2016, accepted: 10 0ctober 2016

\section{Abstract}

The infill of an abandoned branch of the small river Vlootbeek, a tributary of the Meuse, revealed a record of the vegetation history from the Allerød to the Middle Ages, albeit with at least two hiatuses in its upper reach. Striking observations are the continuous presence of Pinus in a period long after this tree was absent elsewhere in the Dutch landscape, and the high percentages of Tilia pollen in the mid-Holocene. The former is explained by the sandy-gravelly subsoil in the valley of the Vlootbeek. The latter is ascribed to the short distance between the coring location and the plateau on which Tilia must have been the dominant tree. Anthropogenic influence is apparent from the Early Neolithic Linearbandkeramik farmers onwards.

Keywords: Anthropogenic influence, Late Pleistocene - Holocene, Pinus, pollen diagram, Tilia

\section{Introduction}

The Vlootbeek is a small tributary of the river Meuse that begins in Germany, enters the Netherlands just south of the village of Posterholt and flows past Montfort to join the Meuse near Linne. The small river has no true source but is actually a branch of the larger river Roer, splitting off before it reaches the border. It makes use of old channels in a fossilised, $2 \mathrm{~km}$ wide valley left by the late Glacial Roer. At the end of the Pleistocene the lower end of this wide valley became partly blocked by the formation of crescentic dunes. This, together with a tectonic tilt of the valley, forced the main stream to the north. The Vlootbeek is the remnant of the former river ( $\mathrm{H}$. Van der Beek, unpublished report, 1998).

In its lower course the Vlootbeek is much affected by canalisation, but near Posterholt the valley reveals traces of the past. A mosaic of former (Roer) channels and low elevations consisting of sandy and gravelly deposits is still visible in, for instance, the locality of Voorsterveld. The former channels are filled with clay and more organic material. One of the channels was sampled for pollen analysis (Fig. 1). Originally this analysis was intended to provide a landscape reconstruction connected with a series of Mesolithic campsites. These sites were the subject of excavations conducted by M. Wansleeben (Faculty of Archaeology, Leiden University) and L. Verhart (Museum of Antiquities, Leiden) in the 1990s, but the final synthesis of this research was never written and the diagram never published.

\section{Material and methods}

The core was taken by the excavators with the use of a sidefilling auger and brought in 1994 to the archaeobotanical laboratory of the Faculty of Archaeology, Leiden University. The RD coordinates of the coring location are X 34651, Y 20046. The lithology is presented in Table 1.

Subsamples of $1 \mathrm{~cm}^{3}$ ( $1 \mathrm{~cm}$ thick) were cut from the core and treated with $\mathrm{KOH}, \mathrm{HCl}$, bromoform/ethanol s.g. 2.0 and acetolysis. Before treatment, a tablet with a known quantity of Lycopodium spores was added following the method of Stockmarr (1971). Pollen was identified and counted by the students Per Larsen and Marjolein Alkemade, and myself. The 


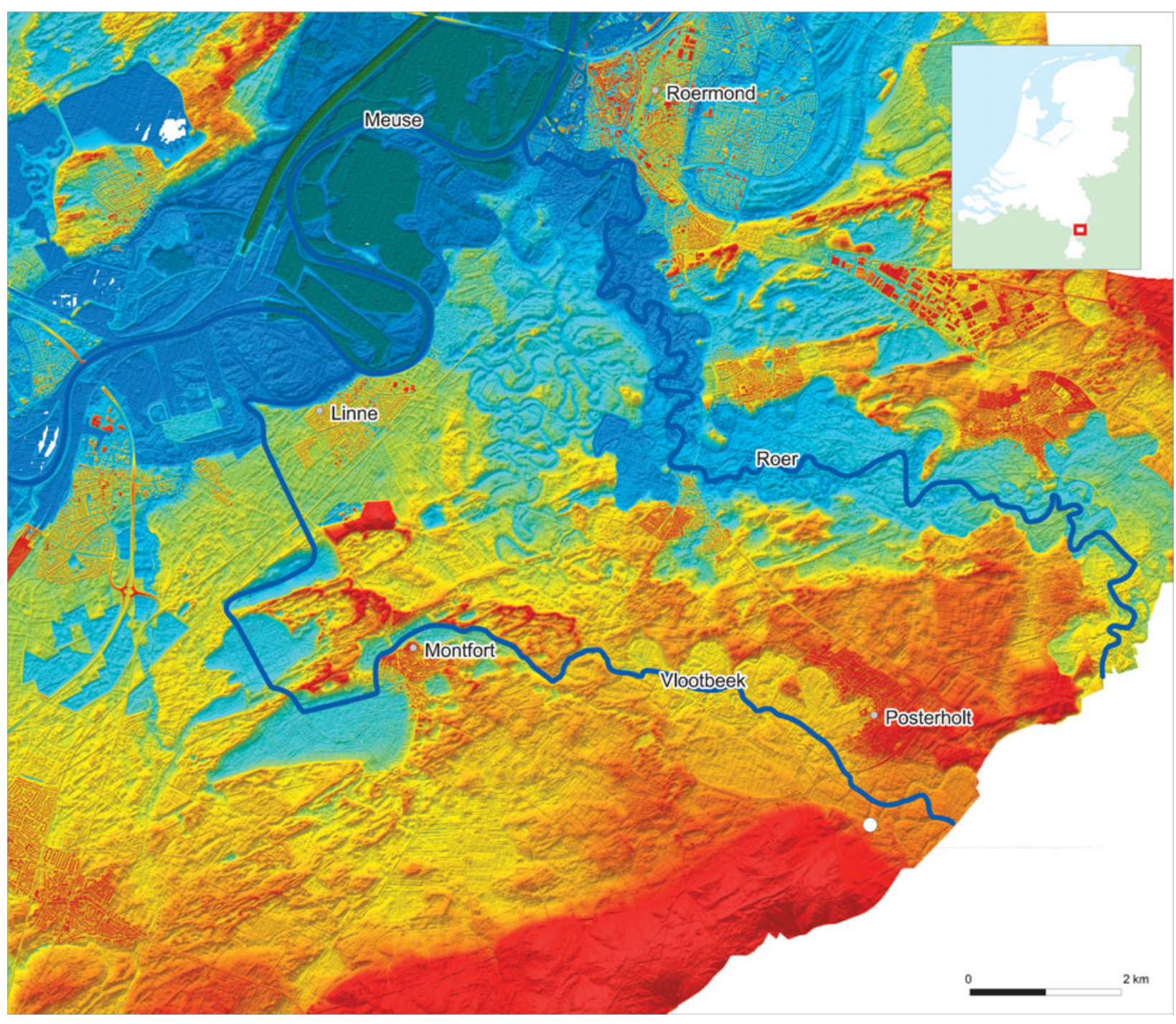

Fig. 1. AHN map of the Vlootbeek and Roer valleys. The location of the core is indicated by a white dot. Highest areas are red, lowest dark blue.

Table 1. Description of the core.

\begin{tabular}{ll}
\hline Depth below surface $(\mathbf{c m})$ & \\
\hline $0-3$ & Peaty clay \\
$3-18$ & Peat \\
$18-21$ & Peaty clay \\
$21-35$ & Peat \\
$35-37$ & Peaty clay \\
$37-78$ & clay \\
$78-86$ & Peaty clay \\
$86-94$ & Clay \\
$94-103$ & Peaty clay \\
$103-118$ & Clay \\
$118-119$ & Gravel \\
$119-121$ & Clay \\
$121-123$ & Peaty clay \\
$123-125$ & Clay \\
End coring & Gravel \\
\hline
\end{tabular}

identification key used was that of Faegri et al. (1989). Some non-pollen palynomorphs were counted with the aid of Pals et al. (1980) and Van Geel et al. (1981, 1989). Diagrams were drawn with the aid of TILIA and TILIAview (Grimm, 2011).

The sediments offered not much material suitable for dating, but five samples were sent to Groningen (the Netherlands) for ${ }^{14} \mathrm{C}$-dating (Table 2).

\section{Results}

The pollen diagram is presented as a percentage diagram in Figure 2. The pollen sum chosen is an upland (dryland) sum excluding all taxa that could have contributed to organic matter in the former channel. These taxa include Alnus, but also Salix, Poaceae and Cyperaceae. In view of the age of the lower part of the sequence this choice may be questionable. This is a well-known dilemma when Late Pleistocene and Holocene records have to appear in a single diagram (see e.g. Janssen \& 
Table 2. Posterholt ${ }^{14} \mathrm{C}$ dates; calibration 0xcal 4.2, 95.4\% probability.

\begin{tabular}{lclrl}
\hline Depth (cm) & \multicolumn{1}{l}{ AMS date } & Sample & \multicolumn{1}{l}{${ }^{14}$ C date } & Vegetation \\
\hline $12-14$ & $3580 \pm 80 \mathrm{BP}$ & GrN-27623 & $2191-1696 \mathrm{cal} \mathrm{BC}$ & bulk peat \\
27 & $5490 \pm 60 \mathrm{BP}$ & GrA-63462 & $4460-4233 \mathrm{cal} \mathrm{BC}$ & hazelnut shell \\
33 & $6310 \pm 40 \mathrm{BP}$ & GrA-65938 & $5367-5215 \mathrm{cal} \mathrm{BC}$ & thin charred twigs \\
$32.5-35$ & $6980 \pm 100 \mathrm{BP}$ & GrN-27624 & $6028-5674 \mathrm{cal} \mathrm{BC}$ & bulk peat \\
91 & $10,260 \pm 80 \mathrm{BP}$ & GrA-23000 & $10443-9766 \mathrm{cal} \mathrm{BC}$ & Salix twig and leaf \\
\hline
\end{tabular}

IJzermans-Lutgerhorst, 1973). Local pollen zones were drawn visually, based on changes in upland taxa percentages.

Zone 1 is characterised by the dominance of Betula. Among the upland herbs Helianthemum may be noted. A substantial part of the Poaceae and Cyperaceae may also have belonged to the upland vegetation. The landscape presents a combination of birch forest and steppe. Nuphar reveals the presence of a lake at the coring location.

In zone 2 Betula is partly replaced by Pinus, Juniperus and Populus. In the upland vegetation Artemisia stands out, together with other steppe elements like Astragalus and again Helianthemum. The strictly local vegetation, represented by, for instance, Myriophyllum verticillatum, M. spicatum and Nuphar, shows that lake-like conditions still prevail.

Zone 3 sees the return of Betula, but the other trees do not disappear entirely. In addition, Salix is seen to have been important, presumably also in the upland. Herbs like Artemisia, Armeria and Plantago maritima indicate that the herb vegetation is still steppe-like. Aquatic taxa are still present but tend to disappear. Zones 1, 2 and 3 must be placed in the Late Pleistocene.

The next zone, zone 4, is characterised by a strong decline in Betula pollen percentages after an initial rise. Juniperus and Populus are absent from this zone onwards. Pinus dominates the record, but the first deciduous taxa, Corylus and Quercus, make their appearance. The border between zones 3 and 4 is sharp and a hiatus in deposition might be expected, but the curves of local taxa, like Myriophyllum verticillatum and Filipendula, do not show anything of the kind. Also, the lithology provides no indication of a hiatus. The lower part of the zone is provided with an accelerator mass spectrometry (AMS) ${ }^{14} \mathrm{C}$ date of $10,260 \pm 80$ BP obtained from a Salix twig and complete leaf. This date may be thought too old, but comparable dates also turn up elsewhere and there is no reason to reject it (Bos et al., 2007).

Zone 5 is a zone of Corylus dominance, but Pinus remains important as well. The percentages of Quercus pollen rise; Ulmus, Hedera and Myrica appear. Traces of herb vegetation are hardly visible. At the start of the zone the sediment is a peaty clay, but during its remainder true clay deposition took place, obviously smothering the former lake.

Zone 6 starts with the appearance of Tilia. Furthermore the highest values of Ulmus are seen in this zone. Pi- nus pollen percentages decline. Herb vegetation is sparsely represented.

Zone 7 is characterised by the dominance of Tilia. Corylus and Pinus pollen percentages decline strongly, but Quercus percentages show a rise. Surprisingly for a zone dominated by Tilia, the herb pollen percentages, expressed in the NAP component of the AP-NAP (arboreal pollen-non-arboreal pollen) diagram, rise as well. This is mainly due to a rise in Ericales and Polypodium, but other herbs also appear. Locally Alnus appears, together with marsh ferns (Monoletae psilatae), indicating the presence of carr and marsh conditions in low-lying areas. At the beginning of this zone the lithology shows a return to stagnant wetland conditions allowing peat formation. $\mathrm{A}{ }^{14} \mathrm{C}$ date, obtained from bulk material at the base of the peat, places this change at $6980 \pm 100 \mathrm{BP}$. The strong changes observed hint at a hiatus in the sequence between zones 6 and 7 . AMS ${ }^{14} \mathrm{C}$ dates obtained for horizons above the bulk material sample give $6310 \pm 40 \mathrm{BP}$ and $5490 \pm 60 \mathrm{BP}$.

The following zone, zone 8 , starts with a sharp decline in Tilia pollen percentages, a rise in Quercus and the start of the continuous curve of Fagus pollen. Carpinus appears, which is rather soon after the appearance of Fagus. A long-lasting hiatus between zones 7 and 8 would explain this. The lithology shows an intercalation of (peaty) clay at this point. It is quite possible that something happened to disturb the smooth continuity of the sequence. A conventional ${ }^{14} \mathrm{C}$ date based on bulk material provides a date of $3580 \pm 80 \mathrm{BP}$ for the centre of the zone and is discussed below.

The last zone, zone 9, shows an important share of upland herb pollen, including Cerealia (mostly Secale), Fagopyrum, Centaurea cyanus and Ericales. Tree pollen comprises Juglans. Locally the Alnus carr with its undergrowth of marsh fern (Monoletae psilatae) appears to decline whilst Typha latifolia pollen percentages rise strongly. During this zone both the upland and the wetland environment were deforested to an important degree.

\section{Discussion}

The Posterholt diagram represents the Late Pleistocene and large parts of the Holocene. Such long records are rare in this part of 
POSTERHOLT

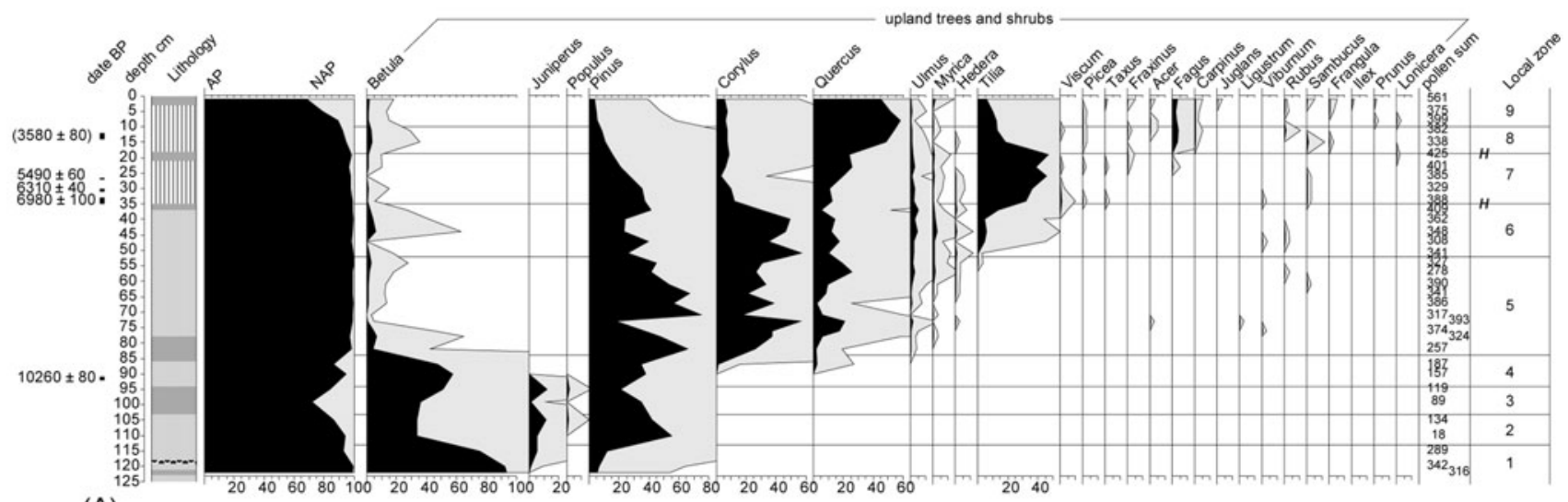

(A)

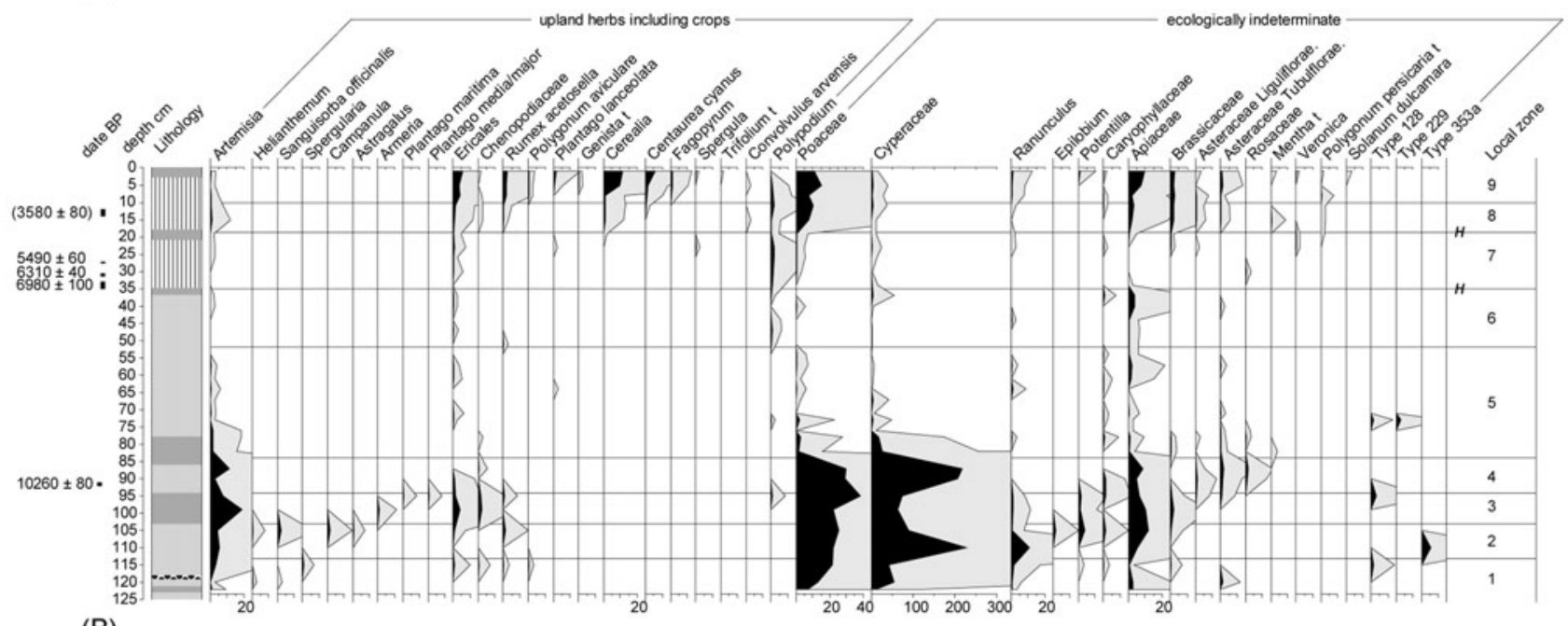

(B)

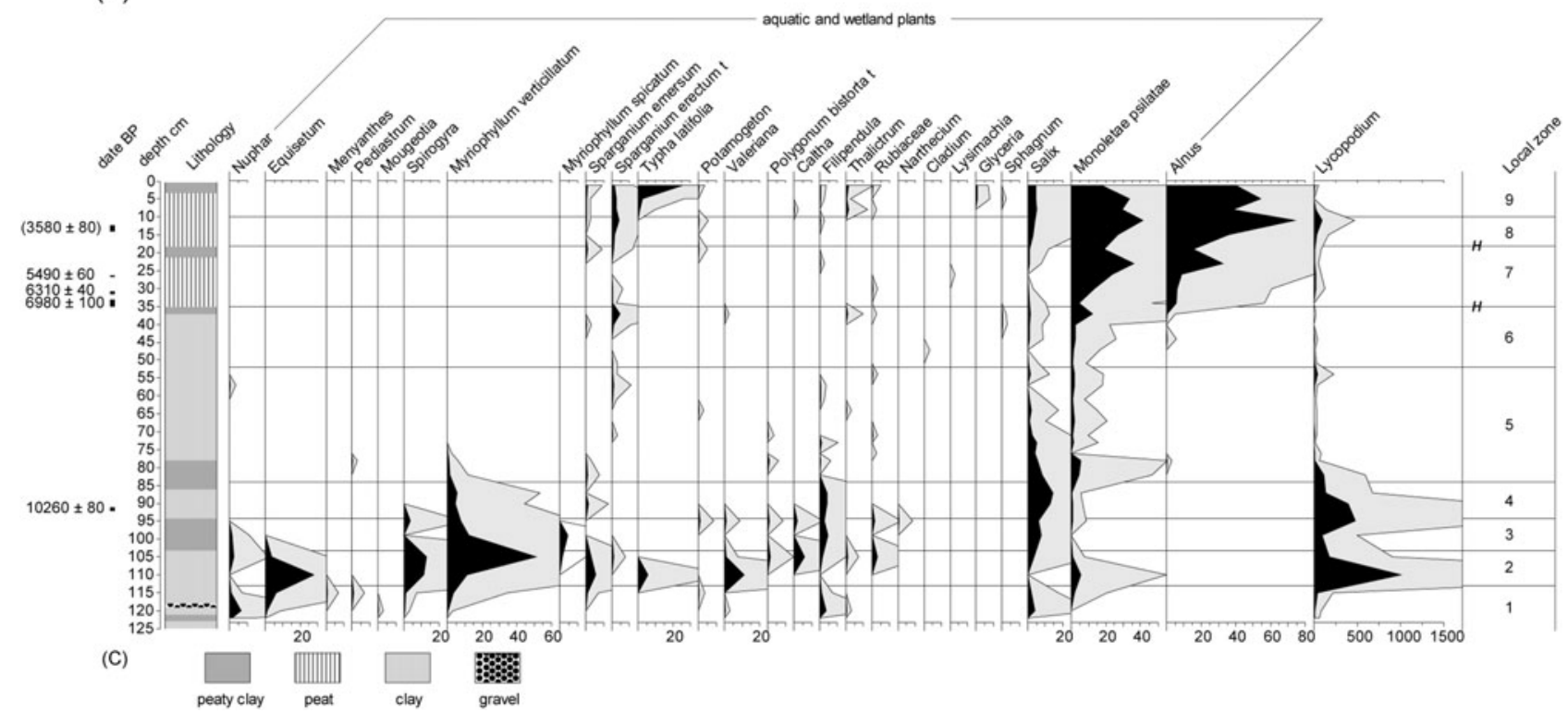

Fig. 2. The Posterholt pollen diagram: (A) upland trees and shrubs; (B) upland herbs including crops, and ecologically indeterminate taxa; (C) aquatic and wetland plants. Depth below surface, exaggeration of curves $10 \times$ in grey. One ${ }^{14} \mathrm{C}$ date (in parentheses) is questionable. Hiatuses are indicated by $\mathrm{H}$ in the local zone column. 
the Netherlands (Bos \& Zuidhoff, 2015, p. 8). It has two hiatuses in its upper reach.

Zones 1 and 2 are attributed to the Allerød. The sequence Betula forest, followed by Pinus-Betula forest together with Juniperus, belongs to this period. The forest was rather open as is indicated by the presence of steppe herbs, first and foremost Artemisia, but also other taxa like Helianthemum and Astragalus, which might not have been detected if the forest had been dense. The pollen reflects an upland covered with a light forest with much undergrowth, or with a mosaic of stands of trees and open patches. The former channel had developed into a (small) lake.

In zone 3 the forest reverted to a dwarf shrub vegetation with scattered Betula copses accompanied by Juniperus and presumably Salix, because part of the Salix pollen may have come from the upland. This change is attributed to the onset of a period with a colder climate, the Younger Dryas. In most parts of the wider region, i.e. the valley of the Meuse and its surroundings, forests disappeared (Hoek, 1997), but as Bos et al. (2007) remarked, in some sheltered places remnants of the original forest survived along small lakes. Posterholt may have been one of those.

After zone 3 the upland vegetation returned to forest as is apparent from the AP-NAP curves. The sequence in which the trees appear is typical for the Holocene in the Netherlands. Zone 4 represents the Preboreal, a period with a dominance of Pinus, but with the first records of the warmth-loving deciduous taxa Corylus, Quercus and Ulmus. The modest thickness of the peaty clay deposited during this period does not afford sufficient resolution to detect subzones such as the Friesland- or Rammelbeekphases (for subzones see e.g. Bos et al., 2007). The local lake has disappeared.

A substantial part of the diagram comprises the Boreal (zones 5 and 6). The share of Pinus in the forests declines but during the Holocene Pinus never disappears. As described in the introduction, the local landscape presented, and still consists of, a mosaic of former channels and sandy-gravelly low elevations. Pinus may very well have survived on the latter. Another explanation for the occurrence of Pinus pollen might be that this pollen was not released by the Vlootbeek valley vegetation but arrived with the clay deposited during this period. Arguments against this hypothesis are that the majority of the pollen grains were undamaged and that other diagrams obtained for the region do not show such high Pinus percentages. The corings Bolberg and Bennebroek, for instance, also revealed clastic sediments in the Boreal, but only a modest share of Pinus (Janssens, 2011). Nevertheless, the pollen may have derived from locally reworked older sediments as the result of Mesolithic huntergatherers' activities (suggestion by A.J. Kalis, oral communication). Consultation with the archaeologists M. Wansleeben and L. Verhart revealed that, though they detected some 30 campsites in the neighbourhood, these were small and short-lived. According to them the impact of the Mesolithic population can- not have been important enough to cause redeposition of older sediments. Therefore, it is quite possible that light local Pinus stands existed and were the source of attraction for the huntergatherers (see for local stands also Bos \& Van Geel, 2016).

The lower ground around the sandy hillocks may have been covered by Myrica brushwood. This shrub grows on moist soils, poor in nutrients and with a low $\mathrm{pH}$. It requires an Atlantic climate; at present the region around Posterholt lies at the southern limit of its distribution in the Netherlands (Weeda et al., 1985). Stands of Myrica are poor in other species, which may explain the near absence of herb pollen in the diagram. Although the lake in the channel that provided the pollen diagram no longer existed at that time, other lakes may still have been present in the maze of former channels. In its entirety the landscape around Posterholt may have presented a desirable environment for hunter-gatherers.

On the better soils, the nearest being the land close to the left bank of the Vlootbeek, south of the place of coring, Corylus gained dominance. Quercus was present in the landscape, but another well-known tree from the mid-Holocene, Ulmus, appears not to have got much chance to establish stands.

A hiatus follows zone 7 that is attributed to the Atlantic, an attribution confirmed by three ${ }^{14} \mathrm{C}$ dates. The nature of the deposit has changed, as has the composition of the vegetation. Myrica loses importance and Alnus carr with an undergrowth of marsh ferns (Monoletae psilatae) appears instead. A new water regime must lie behind this.

The most conspicuous change is the strong presence of Tilia pollen percentages at the expense of Corylus mentioned above. Apparently Tilia becomes the dominant tree; this fact is commented on in a separate section below. According to Berendsen and Zagwijn (1984), the few grains of Taxus suggest a date in the Subboreal. But Taxus berries are well known at ErkelenzKückhoven from the Early Neolithic (Linearbandkeramik) with dendro-dates of 5090 and $5057 \pm 5$ BC (Knörzer, 1989; Schmidt et al., 1998), a locality not far from Posterholt. The TaxusSubboreal connection may not be applicable to this part of the Netherlands. A presence in the second half of the Atlantic is therefore plausible (see also Woldring et al., 2010).

Another remarkable aspect is that despite the dominance of Tilia, which provides much shade, the curves of Quercus and NAP rise. This implies the presence of lighter forest and open space in the landscape. As Tilia forest is supposed to have covered pre-eminently the plateau outside the valley (see below), this more open landscape where Quercus could thrive and herbs could attribute pollen to the pollen rain was to be found in the valley. The local sandy-gravelly soils may not have been suited to Tilia, but this may not be the only explanation. It is tempting to attribute at least part of the openness to farming activities. The area is known to have been exploited from the Early Neolithic Linearbandkeramik culture onwards (Brounen, 1985; Wansleeben, 1987). In particular, the browsing and grazing of livestock may have affected the original vegetation. The 
AMS date of $6310 \pm 40 \mathrm{BP}(5367-5215 \mathrm{cal} \mathrm{BC})$ for the start of the rise in NAP is in accordance with this attribution. The first occupation of the southeastern Netherlands and adjacent Germany occurred between 5300 and 5200 cal BC (Van de Velde, 2007). People settled on loess, but Bakels (1982) suggested that the areas on the fringes of the loess-covered plateaus were needed by Linearbandkeramik farmers as pasture land, as the dense forest on the plateaus may not have offered enough feed. The valley of the Vlootbeek may have been one of these areas.

The values of Tilia fall suddenly at the boundary between zones 7 and 8, and, as argued earlier, this must be due to a hiatus in the record. To a very moderate degree the place of Tilia may have been taken over by Fagus. However, it is Quercus that became the most important tree. The rise in its pollen curve is accompanied by a rise in upland pollen percentages. Quercus does well in open stands and sheds more pollen there, and the general picture is one of a landscape undergoing deforestation. Quercus trees may have been spared. The occurrence of a continuous Cerealia curve shows that part of the landscape was converted into arable fields. The strong rise in Poaceae pollen percentages most probably represents meadows and pastures. The rise in the Ericales curve may be explained as the appearance of pasture land as well, in this case on the poorer soils. $\mathrm{A}^{14} \mathrm{C}$ date based on bulk peat suggests a serious impact on the environment in a period at least around $3580 \pm 80 \mathrm{BP}$ (2191-1696 cal $\mathrm{BC}$ ), that is in the Bronze Age. To a certain degree this date is plausible. The continuous Fagus curve in the Well-Aijen diagram is also placed in the Bronze Age part of the Subboreal (Bos \& Zuidhoff, 2015). However, some pollen grains of Carpinus are also present, which means a Subatlantic date. It is therefore also plausible to attribute the deforestation to farmers of the Iron Age, sometime after $800 \mathrm{cal} \mathrm{BC}$. In that case the ${ }^{14} \mathrm{C}$ date has to be rejected, although there is no obvious reason for its being wrong.

The last spectra give evidence that the uppermost part of the sequence was deposited in the Middle Ages. Although Juglans, a tree introduced by the Romans, may be placed earlier, the presence of Fagopyrum and Centaurea cyanus indicates a medieval age (Bakels, 2012; Bakels et al., 2015).

\section{The importance of lime (Tilia) in the mid-Holocene forest}

An outstanding feature of the Posterholt diagram is the high value reached by Tilia pollen percentages in local zone 7 (Fig. 2). The taxon Tilia represents two species, Tilia cordata Mill. and T. platyphyllos Scop., the only indigenous lime species in the Netherlands. At present, natural lime forests are absent in the country, though a few trees can still be found (Maes \& Van Vuure, 1989). The pollen of the two species display differences (Christensen \& Blackmore, 1988), but there is a non-negligible overlap between the pollen types (see also Beug, 2004, p. 323). At the time of counting, the taxon was not split into a $T$. cordata type and a T. platyphyllos type. Macroremains were not found, but in contemporaneous deposits in the valley of the Elsbach in nearby Germany Tilia fruits were preserved and identified as T. cordata (Becker, 2000). Surprisingly, the Tilia fruits described for contemporaneous deposits in the Netherlands, for instance in the Alblasserwaard and the surroundings of Zwolle, were all described as T. platyphyllos (relational archaeobotanical database for advanced research (RADAR) version 2010, maintained by 0 . Brinkkemper, RCE Amersfoort, Netherlands).

The striking dominance of Tilia is not restricted to Posterholt. K.K. Koelbloed (unpublished report, 1976) found the same at Melick, a locality $6 \mathrm{~km}$ to the northwest of Posterholt, a record repeated by new research at the same locality by M. Van Dinter (unpublished report, 1994). Janssen (1960) and Kalis \& MeurersBalke (2003) detected high percentages of Tilia pollen in some peats of South-Limburg, a region just to the south, and Otten (2013) in abandoned branches of the river Meuse just west of the Vlootbeek area. Munaut (1967) published high percentages in the uplands of Belgian Limburg and Brabant.

Greig (1982) provided an overview of past lime forests in northern and central Europe. He wondered why some pollen diagrams show low percentages of lime whilst others display high percentages. He concludes: "This study has shown evidence that lime forest, rather than as traditionally supposed mixed oak forest, was the dominant vegetation of areas of northern Europe in the Atlantic period ... No clear explanation can yet be advanced to account for its irregular distribution.'

Janssen (1960) sought the explanation in the size of the peat deposit in combination with the bad dispersal of Tilia pollen grains. Tilia is entomophylous. He writes on p. 68: 'high percentages are reached only in case the distance between the site where Tilia trees are growing and the site where the pollen was collected is but small.' Therefore he placed the lime forest in the valleys as part of an Alno-Ulmion (now Alno-Padion). In 1978 I questioned this reconstruction (Bakels, 1978, pp. 34-35) and opted for lime forests on the higher plateaus outside the valleys, inspired by the work of Munaut.

Since then I have been looking into this matter and have twice had the opportunity to compare pollen percentages obtained from a peat in a valley of a larger river with those obtained from the narrower valley of a tributary and to establish the relative contribution of the taxa Tilia, Quercus, Ulmus and Fraxinus, the 'classic' components of the upland forests in the mid-Holocene, formerly taken together as Quercetum mixtum, a now obsolete term (Bakels, 2009). The conclusion was that Tilia percentages are much higher in smaller valleys, which may be explained by the smaller distance from the coring location to the plateau. As a matter of fact the first supposition of Janssen was right, but his conclusion was not.

The combination of Well-Aijen (Bos \& Zuidhoff, 2015) and Posterholt presents a third case. It is clear that Posterholt has 


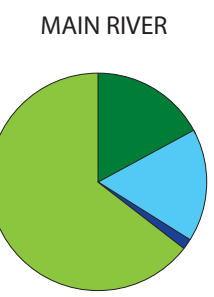

Meuse, Well-Aijen Plateau - 1000 m

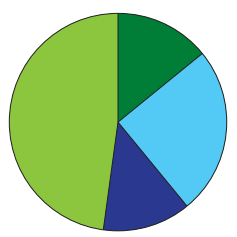

Meuse, Maastricht plateau - $500 \mathrm{~m}$

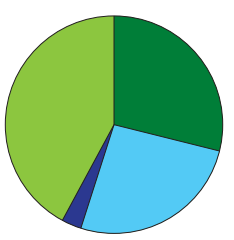

Vesle

Plateau - 1000 m
TRIBUTARY

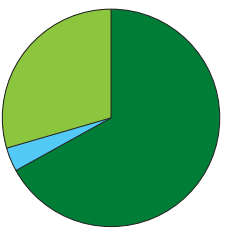

Vlootbeek Plateau - 300 m

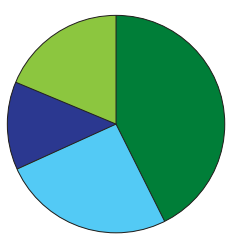

Geleenbeek Plateau - 250 m

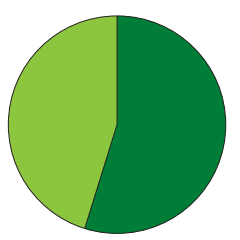

Le Coup de Tonnerre Plateau - $125 \mathrm{~m}$

$\begin{array}{ll}\text { Tilia } & \text { Fraxinus } \\ \text { Ulmus } & \text { Quercus }\end{array}$

Fig. 3. The proportion of the pollen percentages of the main four deciduous trees in the mid-Holocene, average of four spectra per location. The values obtained from a location in the wide valley of a main river are compared with those from a location in the narrower valley of a tributary within the same region. The distances from the coring location to the nearest plateau are mentioned. Three sets are presented: Meuse and Vlootbeek (central Limburg), Meuse and Geleenbeek (southern Limburg), and Vesle and Le Coup de Tonnerre (Aisne, France).

the higher share of Tilia (Fig. 3). Although the valley of the Vlootbeek appears wide on maps, the mid-Holocene valley was not wide at all and the plateau is nearby. Therefore, the reconstruction of a lime forest expressly on the high parts of the landscape is plausible.

Everywhere lime forests disappeared after the mid-Holocene, as on the plateau bordering the Vlootbeek valley. Pollen analyses in adjacent regions of Germany showed that the decline of lime is due to anthropogenic influence (Bunnik, 1999; Knörzer et al., 1999; Becker, 2000). Though the 'sudden' Tilia decline in the Posterholt diagram may be due to a hiatus in the sequence, the diagram reveals the presence of anthropogenic indicators and a rise in Ericales pollen percentages just before the possible gap. It is therefore not unlikely that the lime forests in the vicinity of the Vlootbeek also disappeared as the result of human action.

\section{Conclusion}

The fill of the former channel of the Vlootbeek revealed a substantial part of the vegetation history in and around this branch of the river Roer during the late Pleistocene and the Holocene. The persistence of pine in the record is striking. This tree that commonly almost completely disappears from the Dutch landscape is seen to linger on as a rather important component of the local forest. Most probably, its stands survived on the sandygravelly elevations in the wide valley.

An entirely different vegetation seems to have developed on the plateaus outside the valley, the nearest situated south of the course of the Vlootbeek, where in the Atlantic the landscape appears to be covered by lime forest. The predecessor of this kind of forest was presumably tall hazel shrub.

Valley and plateau together must have presented a variegated landscape that should have been attractive to the huntergatherers of the first half of the Holocene. Farming societies later took root in this region and in the end the landscape underwent severe deforestation. Only oak appears to have been spared in the long run.

During the Holocene the water regime in the part of the Vlootbeek also studied underwent changes. The deposition of clay smothering the former lake is one indication of such change. The occurrence of alder carr in an area where formerly bog myrtle is supposed to have grown is another and suggests a shift from mesotrophic to eutrophic conditions. In all, the surroundings of the Vlootbeek near Posterholt presented a variegated and dynamic landscape throughout the Holocene.

\section{Acknowledgements}

I would like to thank Milco Wansleeben and Leo Verhart for providing me with the core. Hanneke Bos urged me to publish the diagram and sent me the MA thesis of Susan Otten. Cees Kasse and Sjoerd Bohncke provided me with the MSc thesis of Marlies Janssens.

Hans van der Plicht and his laboratory personnel did their utmost to provide me with last-minute AMS datings. Wilko van Zyverden drew the map, Joanne Porck the other figures and Kelly Fennema corrected my English. Last but not least, two reviewers, Joop Kalis and Henk van Haaster, gave me much food for thought.

\section{References}

Bakels, C.C., 1978. Four Linearbandkeramik settlements and their environment: a paleoecological study of Sittard, Stein, Elsloo and Hienheim. Analecta Praehistorica Leidensia 11.

Bakels, C.C., 1982. The settlement system of the Dutch Linearbandkeramik. Analecta Praehistorica Leidensia 15: 31-43. 
Bakels, C.C., 2009. The Western European Loess Belt, agrarian history, 5300 BC AD 1000. Springer (Dordrecht/ Heidelberg/London/ New York): 295 pp.

Bakels, C.C., 2012. The early history of Cornflower (Centaurea cyanus L.) in the Netherlands. Acta Palaeobotanica 52(1): 25-31.

Bakels, C., Langeveld, M. \& Van Tulder, I., 2015. Clearance for a medieval curtis, Black Death and buckwheat (Fagopyrum esculentum Moench): vegetation history of the area around the confluence of the rivers Swalm and Meuse, the Netherlands, AD 800-1900. Analecta Praehistorica Leidensia 45: 123-131.

Becker, W.-D., 2000. Das Elsbachtal, die Geschichte eines Tales vom Endneolithikum bis ins Hochmittelalter. PhD Thesis. Utrecht University (Utrecht): $352 \mathrm{pp}$.

Berendsen, H.J.A. \& Zagwijn, W.H., 1984. Some conclusions reached at the symposium on geological changes in the Western Netherlands during the period 1000-1300 AD. Geologie en Mijnbouw 63: 225-229.

Beug, H.-J., 2004. Leitfaden der Pollenbestimmung für Mitteleuropa und angrenzende Gebiete. Pfeil (München): 542 pp.

Bos, J.A.A., Van der Plicht, J.H., Van Geel, B. \& Bohncke, S.J.P., 2007. Preboreal climate oscillations in Europe: Wigglematch dating and synthesis of Dutch high-resolution multi-proxy records. Quaternary Science Reviews 26: 19271950.

Bos, J.A.A. \& Van Geel, B. 2016. Palaeoenvironmental reconstruction based on the Early Holocene Haelen sequence, near Roermond (southeastern Netherlands). Netherlands Journal of Geosciences / Geologie en Mijnbouw, this issue.

Bos, J.A.A. \& Zuidhoff, F.S., 2015. De restgeul van Well-Aijen. ADC-BAAC rapport.

Brounen, F.T.S., 1985. HVR 183, vroeg-, midden- en laatneolithische vondsten te Echt-Annendaal. Archeologie in Limburg 24: 66-71.

Bunnik, F.P.M., 1999. Vegetationsgeschichte der Lößbörden zwischen Rhein und Maas von der Bronzezeit bis in die frühe Neuzeit. PhD thesis. Utrecht University (Utrecht): $185 \mathrm{pp}$.

Christensen, P.B. \& Blackmore, S., 1988. Tiliaceae. Review of Palaeobotany and Palynology 57: 33-43.

Faegri, K., Kaland, P.E. \& Krzywinski, K., 1989. Textbook of Pollen Analysis, 4th edition. John Wiley and Sons (Chichester): $328 \mathrm{pp}$.

Greig, J., 1982. Past and present lime woods of Europe. In: Limbrey, S. \& Bell, M., (eds): Archaeological aspects of woodland ecology. BAR International Series 146: 23-55.

Grimm, E.C., 2011. TILIA and TILIAView. State Museum (Springfield, IL).

Hoek, W.Z., 1997. Palaeogeography of Lateglacial vegetations. Nederlandse Geografische Studies 230 (Utrecht/Amsterdam).

Janssen, C.R., 1960. On the late-glacial and post-glacial vegetation of SouthLimburg (Netherlands). North-Holland Publishing Company (Amsterdam): $112 \mathrm{pp}$.

Janssen, C.R. \& and IJzermans-Lutgerhorst, W., 1973. A "local" Late-Glacial pollen diagram from Limburg, Netherlands. Acta Botanica Neerlandica 22(3): 213-220.

Janssens, M., 2011. Holocene floodplain development of the river Rur: allogenic or autogenic forcing mechanisms. MSc Thesis. University of Amsterdam (Amsterdam): $56 \mathrm{pp}$.
Kalis, A.J. \& Meurers-Balke, M. 2003. Zur pflanzensoziologischen Deutung archäbotanischer Befunde; zwei Pollendiagramme aus dem Wurmtal (Aldenhovener Platte). In: Eckert, J., Eisenhauer, U. \& Zimmermann, A. (eds): Archäologische Perspektiven. Analysen und Interpretationen im Wandel. Marie Leidorf GmbH (Rahden/Westfalen): 251-277.

Knörzer, K.-H., 1989. Botanische Untersuchungen am bandkeramischen Brunnen von Erkelenz-Kückhoven. In: Koschik, H. (ed.): Brunnen der Jungsteinzeit. Rheinland-Verlag (Köln)/Rudolf Habelt (Bonn): 229269.

Knörzer, K.-H., Gerlach, R., Meurers-Balke, J., Kalis, A.J., Tegtmeier, U., Becker, W.-D. \& Jürgens, A., 1999. PflanzenSpuren, Archäobotanik im Rheinland: Agrarlandschaft und Nutzpflanzen im Wandel der Zeiten. Rheinland-Verlag (Köln)/Budolf Habelt (Bonn): 185 pp.

Maes, N. \& Van Vuure, T., 1989. De Linde in Nederland. Stichting Kritisch Bosbeheer: $166 \mathrm{pp}$.

Munaut, A.V., 1967. Recherches Paleo-ecologiques en Basse et Moyenne Belgique. Acta Geographica Lovaniensia 6.

Otten, S.P.M., 2013. Fluvial response of the river Maas to Lateglacial and Early Holocene climate and vegetation changes in Limburg, S.-Netherlands. MA thesis. Utrecht University (Utrecht): 47 pp.

Pals, J.P., Van Geel, B. \& Delfos, A. 1980. Palaeoecological studies in the Klokkeweel bog near Hoogkarspel (Prov. of Noord Holland). Review of Palaeobotany and Palynology 30: 371-418.

Schmidt, B., Höfs, E., Khalessi, M. \& Schemainda, P., 1998. Dendrochronologische Befunde zur Datierung des Brunnens von Erkelenz-Kückhoven. In: Koschik, H., (ed.): Brunnen der Jungsteinzeit. Rheinland-Verlag (Köln)/Rudolf Habelt (Bonn): 229-269.

Stockmarr, J., 1971. Tablets with spores used in absolute pollen analysis. Pollen Spores 13: 615-621.

Van de Velde, P., 2007. On chronology: pot sherds, house ghosts and carbonized seeds. Analecta Praehistorica Leidensia 39: 205222.

Van Geel, B., Bohncke, S.J.P. \& Dee, H., 1981. A palaeoecological study of an upper Late Glacial and Holocene sequence from "De Borchert". The Netherlands. Review of Palaeobotany and Palynology 31: 367448.

Van Geel, B., Coope, G.R. \& Van der Hammen, T., 1989. Palaeoecology and stratigraphy of the Lateglacial type section at Usselo (the Netherlands). Review of Palaeobotany and Palynology 60: 25-129.

Wansleeben, M., 1987. Spatial analysis of Late Mesolithic and Neolithic surface scatters: a test case of the Roerstreek (Middle Limburg). Analecta Praehistorica Leidensia 20: 11-26.

Weeda, E.J., Westra, R., Westra, Ch. \& Westra, T., 1985. Nederlandse oecologische flora 1. IVN/Vara/Vewin (Amsterdam): $304 \mathrm{pp.}$

Woldring, H., Cleveringa, P. \& Van Smeerdijk, D.G., 2010. Taxus vroeger en nu: de veelzijdige naaldboom / Taxus then and now, the versatile coniferous tree. In: Bakels, C., Fennema, K., Out, W.A. \& Vermeeren, C. (eds.): Van planten en slakken. Sidestone Press (Leiden): 247-269. 